\title{
Short communication: Assessing the accuracy of inline milk fat-to-protein ratio data as an indicator of hyperketonemia in dairy cows in herds with automated milking systems
}

\author{
M. T. M. King, ${ }^{1}$ T. F. Duffield, ${ }^{2}$ and T. J. DeVries ${ }^{1 *}$ \\ ${ }^{1}$ Department of Animal Biosciences, University of Guelph, Guelph, Ontario, N1G 2W1, Canada \\ ${ }^{2}$ Department of Population Medicine, University of Guelph, Guelph, Ontario, N1G 2W1, Canada
}

\begin{abstract}
The objective of this study was to evaluate the accuracy of inline milk fat-to-protein $(\mathrm{F}: \mathrm{P})$ data to detect hyperketonemia (HYK) in herds with automated milking systems (AMS). The F:P ratio has been investigated as a tool for detecting HYK with moderate accuracy in past studies, but inline F:P data in AMS may also be useful for HYK screening. To assess the accuracy of these data in commercial settings, we monitored 484 cows from 9 AMS herds for their first 3 wk of lactation, taking blood samples once per week $(\mathrm{n}=1,427)$. Positive cases of HYK were defined by whole-blood $\beta$-hydroxybutyrate (BHB) concentrations $\geq 1.2$ or $\geq 1.4$ $\mathrm{mmol} / \mathrm{L}$. Milk data were collected from the AMS software on each farm for each cow and converted into 4 different $\mathrm{F}: \mathrm{P}$ values: (1) value from the same day as the BHB test; (2) 5-d centered-moving average (CMA); (3) 5 -d backward-moving average (BMA); (4) 5-d forwardmoving average (FMA). In linear regression models, all 4 values were associated with $\mathrm{BHB}$, but slope estimates varied and $\mathrm{R}^{2}$ were low: same day (slope $=0.95, \mathrm{R}^{2}$ $=0.07$ ), CMA (slope $=1.05, \mathrm{R}^{2}=0.07$ ), BMA (slope $=0.65, \mathrm{R}^{2}=0.04$ ), and FMA (slope $=1.23, \mathrm{R}^{2}=$ 0.09). In logistic regression models, the odds of having HYK (BHB $\geq 1.2 \mathrm{mmol} / \mathrm{L})$ increased with every 0.1-unit increase from the mean F:P ratio (1.16) using same-day values (odds ratio $=1.35,95 \%$ confidence interval $=1.25-1.47$ ) and CMA (odds ratio $=1.39,95 \%$ confidence interval $=1.27-1.51)$. The same increase in F:P from mean BMA (1.14) and FMA (1.17) was associated with 1.22 and 1.49 times the odds of HYK, respectively. For all 4 F:P variations, we evaluated the sensitivity, specificity, positive predictive value, and negative predictive value of different $\mathrm{F}: \mathrm{P}$ thresholds with HYK status. As the F:P threshold increased from 1.17 to 1.50 , sensitivity decreased (range: 77 to $9 \%$ )
\end{abstract}

Received November 28, 2018.

Accepted March 18, 2019.

*Corresponding author: tdevries@uoguelph.ca but specificity increased (range: 58 to $96 \%$ ). Same-day and CMA F:P cutoffs at which a balance was reached between sensitivity and specificity ranged from 1.18 to 1.22; however, even at these values we found high rates of false positives and negatives (range: $31-39 \%$ ). These results suggest that inline milk $\mathrm{F}: \mathrm{P}$ data from inconsistently calibrated sensors should not be used alone to detect HYK in AMS herds.

Key words: robotic milking, dairy cow, hyperketonemia

\section{Short Communication}

Tools used by dairy producers to help with illness detection should be affordable, noninvasive, and easy to use. A common fresh cow health disorder is hyperketonemia (HYK), which results when early-lactation cows experience excessive negative energy balance. During negative energy balance, the body breaks down fat stores as a source of energy. In the liver, fatty acids are converted to acetyl-CoA, but when available acetylCoA exceeds the capacity of the Krebs cycle, some is converted to ketone bodies (ketogenesis; White, 2015). This increases the concentrations of circulating ketone bodies in the blood, milk, and urine (Ingvartsen, 2006). Of the 3 forms of ketone bodies - acetone, acetoacetate, and BHB - the latter is used most commonly to diagnose HYK and has been referred to as the "gold standard" because of its stability in blood (Oetzel, 2007).

Dairy producers can identify HYK using milk, urine, and blood samples, but using milk is the most convenient way to sample every cow (Oetzel, 2007). Specifically, milk component sampling has been suggested as a convenient tool for the detection of HYK in earlylactation dairy cows (Duffield et al., 1997; Čejna and Chladek, 2005; Jenkins et al., 2015). Potential measures include the percentages of milk fat and protein, as well as the milk fat-to-protein ratio (F:P; Duffield, 2000). Nir Markusfield (2003) reported that the odds of a cow being clinically ketotic increased by 2.1 times with milk F:P ratios of $>1.38$. Translated in Čejna and Chladek (2005), Richardt (2004) reported that F:P 
values $>1.5$ increased the risk of ketosis by 3.5 times. Duffield et al. (1997) obtained sensitivities and specificities ranging from 25 to $97 \%$ and determined that the optimal threshold for detecting subclinical ketosis using a receiver operating characteristic curve was a protein-to-fat ratio of 0.75 (F:P of 1.33), which had a sensitivity of $58 \%$ and a specificity of $69 \%$. However, those authors did not report the number of days between the milk test date and blood sampling, and only reported an average of $7 \mathrm{~d}$ between these samples. Most recently, Jenkins et al. (2015) assessed F:P thresholds of $>1.25,>1.35,>1.42,>1.50,>1.60$, and $>1.70$ and reported sensitivities and specificities of 100 and $49 \%$, 96 and 59\%, 92 and 65\%, 75 and $78 \%, 33$ and 90\%, and 8 and $96 \%$, respectively. Using a receiver operating characteristic curve, they determined the optimal F:P cutoff to be 1.42; the optimal F:P threshold to balance sensitivity and specificity was 1.50 .

Despite only moderate accuracy of $\mathrm{F}: \mathrm{P}$ ratios shown in past studies, inline F:P data from automated milking systems (AMS) have been promoted commercially for HYK detection; thus, using such data, producers may be misdiagnosing or missing some cases of HYK. The objective of this study was to evaluate inline $\mathrm{F}: \mathrm{P}$ ratios from AMS before, during, and after identification of HYK. We hypothesized that inline F:P ratios would not be an adequate method of early HYK detection, because changes in milk fat would reflect the health status of the cow only after it had experienced the effects of the illness.

This study was approved by the University of Guelph Research Ethics Board (REB \#14AP015) and the University of Guelph Animal Care Committee (AUP \#3140). Nine herds in close proximity $(<140 \mathrm{~km})$ to the University of Guelph (Guelph, ON, Canada) were enrolled based on the criteria that they milked Holstein cows exclusively in an AMS and had done so for a minimum of 6 mo. We performed sample-size calculations to determine the number of cows needed to detect daily differences in the primary outcome variables (including rumination time and milk yield) for a related study (King et al., 2018). On the day the study began, producers milked $93 \pm 43$ (mean $\pm \mathrm{SD}$ ) cows with $1.9 \pm$ 1.1 AMS units (Lely Astronaut 4, Lely Industries N.V., Maassluis, the Netherlands). All 9 farms used free cow traffic, and all but one housed the main milking herd in freestalls (the other housed cows on a bedded pack). Fresh cows were housed in bedded packs $(\mathrm{n}=1$ farm), freestalls ( $\mathrm{n}=4$ farms), or both $(\mathrm{n}=4$ farms), depending on the farm and each cow's stage of lactation and health status. The previous 305-d milk yield for multiparous cows enrolled in the study was $10,098 \pm$ $2,332 \mathrm{~kg}$ (mean $\pm \mathrm{SD})$.
Farms were visited once per week, on the same day each week, throughout the study period (June 15, 2016 , to November 29, 2016). All cows $(\mathrm{n}=484)$ were enrolled upon freshening and followed for $3 \mathrm{wk}$. Milk composition (fat and protein \%) and production data (milk yield for each milking and per day) were measured by the AMS and recorded automatically by the AMS software. These data were downloaded upon each farm visit. Hyperketonemia was determined by wholeblood BHB concentrations. Samples were taken once per week, at the same time relative to feeding each week on every farm, within 2 to $4 \mathrm{~h}$ of a fresh feed delivery, to assess the highest BHB possible (Nikkhah et al., 2008). For each sampling, cows were restrained in a lying stall or headlock to obtain a small blood sample from the coccygeal vein using a needled syringe. The BHB concentration was tested immediately using an electronic handheld device (Precision Neo meter, Abbott Diabetes Care, Mississauga, ON, Canada; validated by Kanz et al., 2015). The blood BHB concentration was recorded on the farm; BHB values $\geq 1.2$ and $\geq 1.4 \mathrm{mmol} / \mathrm{L}$, respectively, were classified as cases of HYK (Geishauser et al., 1998; McArt et al., 2012). We tested 2 cutoffs for BHB that are commonly reported in the literature and associated with maximal sensitivity and specificity for displaced abomasum, metritis, and clinical ketosis occurrence (Duffield et al., 2009; Raboisson et al., 2014)

Daily cow-level data were organized such that milk data were compared against corresponding BHB test results. We analyzed linear regressions of BHB to F:P ratios using the regression procedure of SAS (SAS Institute, 2013). We used 4 variations of calculations for F:P values, each relative to the day of the BHB test: (1) the value from the same day as the BHB test; (2) 5 -d centered-moving average; (3) 5-d backward-moving average; and (4) 5-d forward-moving average. Logistic regressions (PROC GLIMMIX; SAS Institute, 2013) were used to identify associations of $\mathrm{F}: \mathrm{P}$ with the odds of having ketosis (BHB $\geq 1.2$ and $\geq 1.4 \mathrm{mmol} / \mathrm{L}$ ), based on the 4 different calculations for $\mathrm{F}: \mathrm{P}$ values. Finally, chi-squared tests that balanced sensitivity and specificity were used to determine the accuracy of the various $\mathrm{F}: \mathrm{P}$ thresholds to identify high $\mathrm{BHB}$ values (PROC FREQ; SAS Institute, 2013).

The incidence of HYK based on BHB $\geq 1.2$ and $\geq 1.4$ $\mathrm{mmol} / \mathrm{L}$, respectively, was 165/484 (34\%) and 124/484 $(26 \%)$ cows. These values were similar to the findings from previous reports of early-lactation cows in Ontario who were blood-sampled once per week (44\% incidence using a $1.2 \mathrm{mmol} / \mathrm{L}$ cutoff in Kaufman et al., 2016) or who were assessed by their first DHI milk test between 5 and 30 DIM (21\% prevalence using $\geq 0.15 \mathrm{mmol} / \mathrm{L}$ in 
Tatone et al., 2017). Our methodology may have underestimated the incidence of HYK, because we bloodsampled only once per week, and some cows may have developed and recovered from HYK between samples; however, the overall incidence lay within the expected range.

Figure 1 shows linear associations between BHB and the different F:P calculations, all of which were signifi-
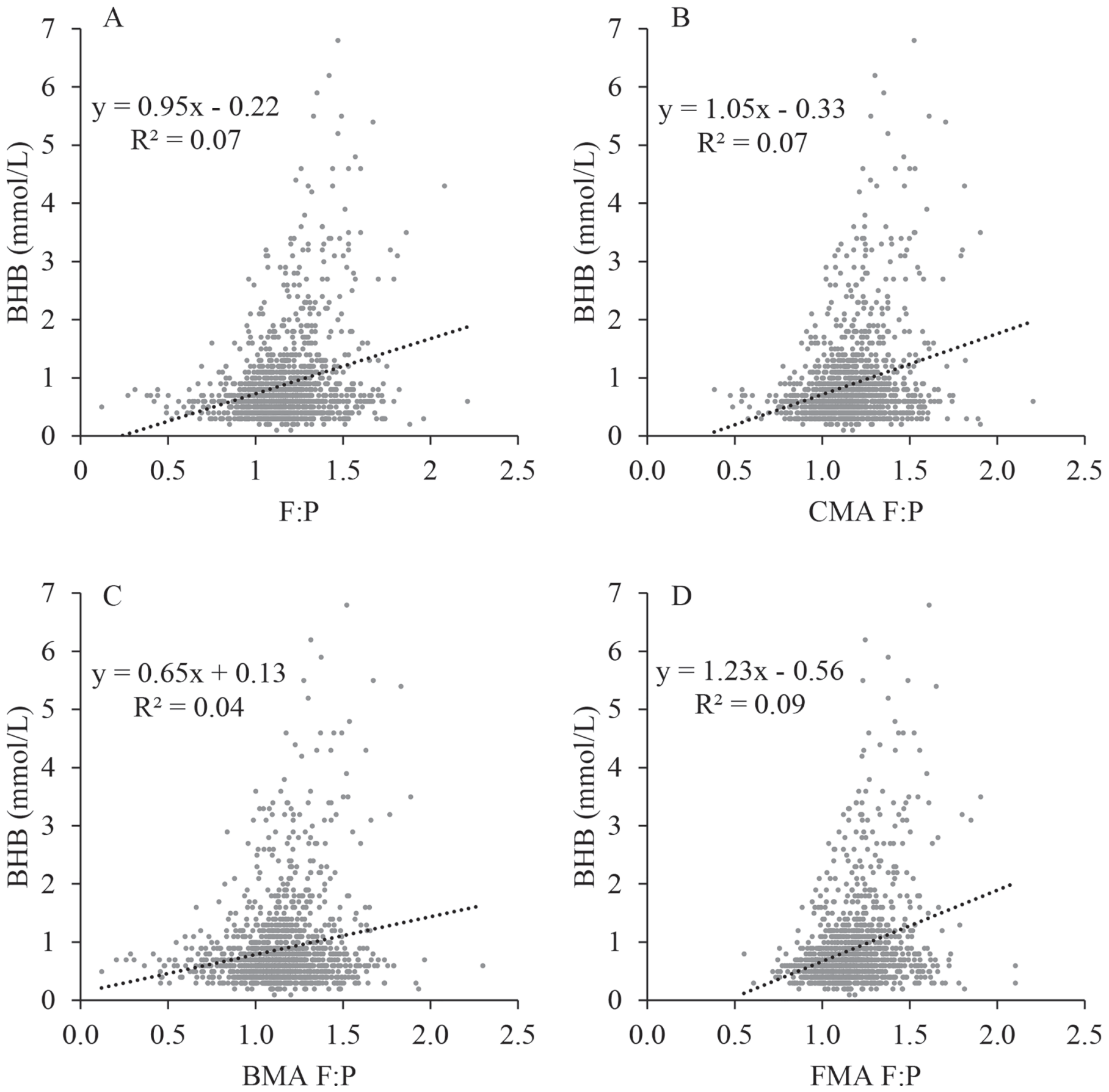

Figure 1. Linear regressions of milk fat-to-protein ratio (F:P) against BHB concentrations $(\mathrm{n}=1,427$ tests from 484 cows on 9 farms with automated milking systems). (A) Milk F:P on day of BHB test. (B) Centered-moving average (CMA) using $5 \mathrm{~d}$ of F:P data (2 d before, 2 d after, and day of BHB test). (C) Backward-moving average (BMA) using $5 \mathrm{~d}$ of $\mathrm{F}: \mathrm{P}$ data (4 d before and day of BHB test). (D) Forward-moving average (FMA) using $5 \mathrm{~d}$ of $\mathrm{F}: \mathrm{P}$ data (4 $\mathrm{d}$ after and day of BHB test). 
cant $(P<0.001)$ : on the same day as BHB tests (Figure $1 \mathrm{~A})$, 5-d centered-moving average (CMA; Figure 1B), 5-d backward-moving average (BMA; Figure 1C), and 5 -d forward-moving average (FMA; Figure 1D). Although these associations were statistically significant, $\mathrm{R}^{2}$ values were very low (0.04 to 0.09$)$ and we observed wide variability. For each calculation of F:P, the odds of having HYK increased by $\sim 1.2$ to 1.5 times (Table 1 ) with each increase of 0.1 in $\mathrm{F}: \mathrm{P}$ from the mean (1.14 to 1.17; Table 1). Increased odds of HYK with higher F:P have also been documented by Nir Markusfield (2003) and Richardt (2004). This is likely due to the increased availability of BHB and fatty acids for milk fat synthesis (Duffield, 2000).

When we evaluated the sensitivities and specificities of different F:P ratios for HYK (Table 2), we found that the performance of $\mathrm{F}: \mathrm{P}$ ratio in detecting $\mathrm{HYK}$ was quite poor. The cutoff at which a balance was reached between sensitivity and specificity ranged from 1.18 to 1.22; however, even at these cutoffs, we found high rates of false positives and negatives (ranging from 31 to $39 \%$ ), and this threshold was much lower than the 1.50 shown by Jenkins et al. (2015) to balance sensitivity and specificity. The cutoffs at which the maximum sum of sensitivity and specificity were reached using same-day F:P values were also 1.18 to 1.22 , again much lower than the optimal thresholds of 1.42 (Jenkins et al., 2015) and 1.33 (Duffield et al., 1997) determined using receiver operating characteristic curves. Even at those optimal thresholds, those researchers were obtaining sensitivities of only 58 to $92 \%$ and specificities of only

Table 1. Logistic regression models for associations between milk fatto-protein ratio ( $\mathrm{F}: \mathrm{P})$ and risk of having blood $\mathrm{BHB} \geq 1.2 \mathrm{mmol} / \mathrm{L}$ ( $\mathrm{n}=1,427$ tests from 484 cows on 9 farms with automated milking systems) $)^{1}$

\begin{tabular}{lccc}
\hline & \multicolumn{3}{c}{ Odds ratio $^{2}$} \\
\cline { 2 - 4 } Variable (F:P) & Estimate & $95 \%$ CI & $P$-value \\
\hline BHB $\geq 1.2 \mathrm{mmol} / \mathrm{L}$ & 1.35 & $1.25-1.47$ & $<0.001$ \\
Same day & 1.39 & $1.27-1.51$ & $<0.001$ \\
5-d CMA & 1.22 & $1.13-1.32$ & $<0.001$ \\
5-d BMA & 1.49 & $1.35-1.64$ & $<0.001$ \\
5-d FMA & & & \\
BHB $\geq 1.4$ mmol/L & 1.41 & $1.29-1.54$ & $<0.001$ \\
Same day & 1.43 & $1.30-1.57$ & $<0.001$ \\
5-d CMA & 1.26 & $1.16-1.37$ & $<0.001$ \\
5-d BMA & 1.50 & $1.36-1.66$ & $<0.001$ \\
5-d FMA & &
\end{tabular}

${ }^{1}$ Same day $=\mathrm{F}: \mathrm{P}($ mean $=1.16)$ on day of BHB test; $\mathrm{CMA}=$ centered-moving average (mean $=1.16)$ using $5 \mathrm{~d}$ of $\mathrm{F}: \mathrm{P}$ data $(2 \mathrm{~d}$ before, $2 \mathrm{~d}$ after, and day of BHB test); BMA = backward-moving average (mean $=1.14$ ) using $5 \mathrm{~d}$ of $\mathrm{F}: \mathrm{P}$ data ( $4 \mathrm{~d}$ before and day of BHB test); FMA $=$ forward-moving average $($ mean $=1.17)$ using $5 \mathrm{~d}$ of $\mathrm{F}: \mathrm{P}$ data (4 d after and day of BHB test).

${ }^{2}$ Adjusted odds ratio and $95 \%$ CI for an increase of 0.1 in F:P from the mean.

Journal of Dairy Science Vol. 102 No. 9, 2019

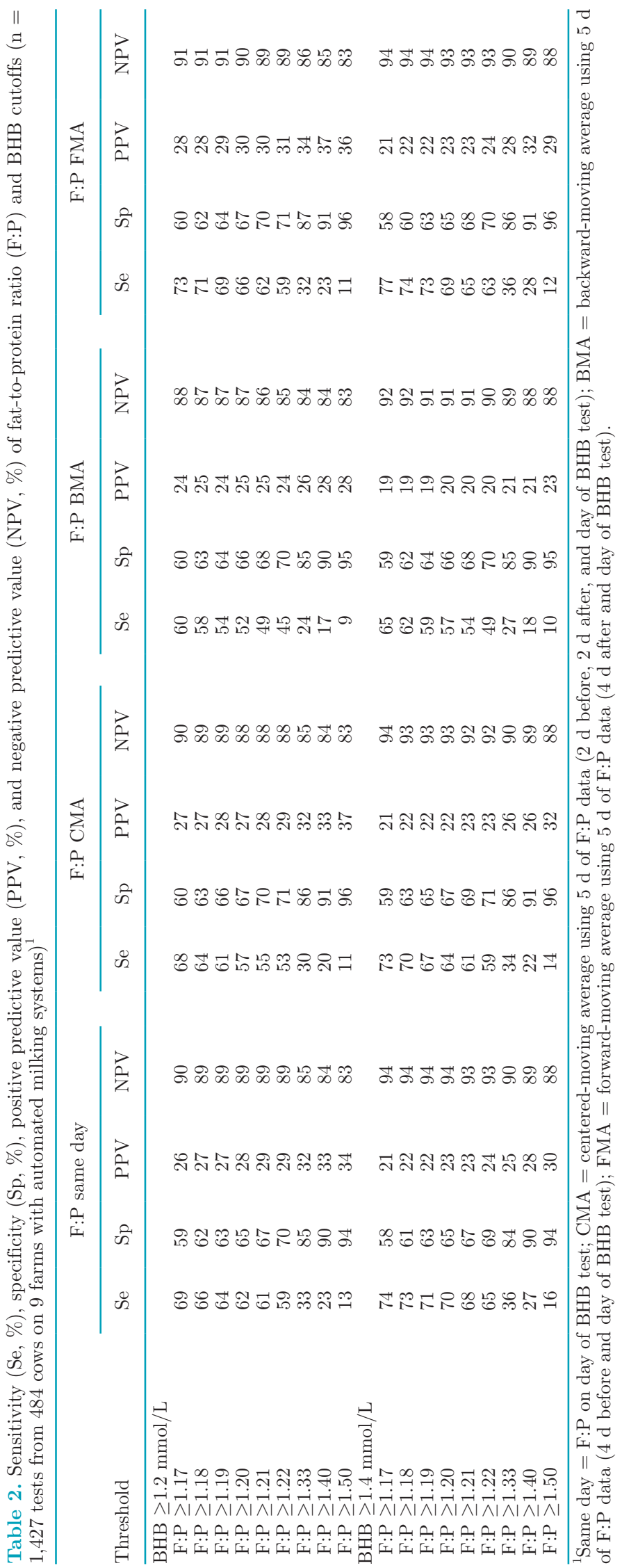


65 to $69 \%$ (Duffield et al., 1997; Jenkins et al., 2015). In the current observational study, if we had we used higher cutoffs, the specificity would have been much higher, but we would have missed 3 to 9 out of every 10 cows with HYK (Table 2). Negative predictive values ranged from 83 to $94 \%$, but positive predictive values ranged from only 19 to $34 \%$ (Table 2). Therefore, inline milk F:P ratio from AMS alone should not be used to detect HYK.

A challenge with the accuracy of using F:P ratio as an indicator of HYK is the fact that milk fat and protein content may be related to many other factors besides energy balance in early lactation. Milk fat content may not only reflect the level of circulating adipose fatty acids (Duffield, 2000; Herdt, 2000); diet and rumen health (i.e., acidosis) may also have large effects during this period (Plaizier et al., 2009). Similarly, dietary factors (including the availability of limiting amino acids) significantly affect milk protein content (Schwab and Broderick, 2017). Most importantly, a large potential source of the low accuracy of $\mathrm{F}: \mathrm{P}$ ratios to indicate HYK is that the farms in this study calibrated their fat and protein sensors very infrequently; within and between farms, this ranged from once per week to once per year. Similar findings have been reported by other researchers; according to Kamphuis et al. (2016), "calibration is an important prerequisite for good sensor performance but is often neglected." Some producers tried to calibrate weekly, but most study participants calibrated their sensors every 2 to 6 mo. This calibration was previously done at the cow level using individual milk sample results, but now the process is much simpler and uses bulk tank values (Fadul-Pacheco et al., 2018). Therefore, even farms with AMS who are no longer participating in regular DHI testing can easily calibrate their fat and protein sensors using bulk tank values obtained from daily pick-ups. However, calibrating at the bulk tank level has potential issues because of (1) an inherent bias of $3 \%$ in Canada when converting units from liters to kilograms, and (2) multiple AMS units per farm contribute to one bulk tank value, which is used to calibrate sensors on multiple AMS (FadulPacheco et al., 2018). Additionally, milk fat and protein are generally underestimated by AMS sensors, but during early lactation the AMS may underestimate fat and overestimate protein (Fadul-Pacheco et al., 2018). This would skew the perceived F:P ratios to be lower than they truly are, which may have been the case in the current study, based on the low average F:P compared to what has been previously reported in the literature. It is possible that, with more frequent sensor calibration, there would be less error associated with milk component data. However, this would not necessarily lead to greater accuracy of F:P for HYK detection.
Overall, despite the strong linear associations of blood BHB with F:P ratios in milk, coefficients of determination were very low and no F:P ratio threshold provided acceptable sensitivity and specificity for identifying HYK. The infrequent and inconsistent calibration of milk component sensors, both within and between farms, is one possible source for this low accuracy. Therefore, the results of this study suggest that inline milk F:P data from inconsistently calibrated sensors should not be used alone to detect HYK in AMS herds.

\section{ACKNOWLEDGMENTS}

We are especially grateful to the participating producers who allowed us access to their animals and AMS data. Robyn Walsh (Grand River Robotics, Ontario, Canada) kindly helped us recruit farms and provided technical support throughout the project. Thank you to those who helped collect data, including Isabela Salmazo, Emily Kaufman, Felipe Pádua, Kaitlin Sparkman, Michelle Thompson, and Sarah McPherson, all from the University of Guelph (Ontario, Canada). This project was financially supported by a contribution from the Dairy Research Cluster II Initiative, funded by the Dairy Farmers of Canada (Ottawa, ON, Canada), Agriculture and Agri-Food Canada (Ottawa, ON, Canada), the Canadian Dairy Network (Guelph, ON, Canada), and the Canadian Dairy Commission (Ottawa, ON, Canada), as well as in part by funding from the Canada First Research Excellence Fund (Ottawa, ON, Canada).

\section{REFERENCES}

Čejna, V., and G. Chladek. 2005. The importance of monitoring changes in milk fat to milk protein ratio in Holstein cows during lactation. J. Cent. Eur. Agric. 6:539-546.

Duffield, T. 2000. Subclinical ketosis in lactating dairy cattle. Vet. Clin. North Am. Food Anim. Pract. 16:231-253. https://doi.org/ 10.1016/S0749-0720(15)30103-1.

Duffield, T. F., D. F. Kelton, K. E. Leslie, K. D. Lissemore, and J. H. Lumsden. 1997. Use of test day milk fat and milk protein to detect subclinical ketosis in dairy cattle in Ontario. Can. Vet. J. 38:713-718.

Duffield, T. F., K. D. Lissemore, B. W. McBride, and K. E. Leslie. 2009. Impact of hyperketonemia in early lactation dairy cows on health and production. J. Dairy Sci. 92:571-580. https://doi.org/ $10.3168 /$ jds.2008-1507.

Fadul-Pacheco, L., M. Séguin, R. Lacroix, M. Grisé, E. Vasseur, and D. Lefebvre. 2018. Characterization of milk composition and somatic cell count estimates from automatic milking systems sensors. Pages 53-63 in ICAR Technical Series no. 23. ICAR, Rome, Italy.

Geishauser, T., K. Leslie, D. Kelton, and T. Duffield. 1998. Evaluation of five cowside tests for use with milk to detect subclinical ketosis in dairy cows. J. Dairy Sci. 81:438-443. https://doi.org/10.3168/ jds.S0022-0302(98)75595-X.

Herdt, T. H. 2000. Ruminant adaptation to negative energy balance: Influences on the etiology of ketosis and fatty liver. Vet. Clin. North Am. Food Anim. Pract. 16:215-230. https://doi.org/10 .1016/S0749-0720(15)30102-X.

Ingvartsen, K. L. 2006. Feeding- and management-related diseases in the transition cow. Physiological adaptations around calving and 
strategies to reduce feeding-related diseases. Anim. Feed Sci. Technol. 126:175-213.

Jenkins, N. T., G. Peña, C. Risco, C. C. Barbosa, A. Vieira-Neto, and K. N. Galvão. 2015. Utility of inline milk fat and protein ratio to diagnose subclinical ketosis and to assign propylene glycol treatment in lactating dairy cows. Can. Vet. J. 56:850-854.

Kamphuis, C., B. T. Dela Rue, and C. R. Eastwood. 2016. Field validation of protocols developed to evaluate in-line mastitis detection systems. J. Dairy Sci. 99:1619-1631. https://doi.org/10.3168/jds .2015-10253.

Kanz, P., M. Drillich, D. Klein-Jöbstl, B. Mair, S. Borchardt, L. Meyer, I. Schwendenwein, and M. Iwersen. 2015. Suitability of capillary blood obtained by a minimally invasive lancet technique to detect subclinical ketosis in dairy cows by using 3 different electronic hand-held devices. J. Dairy Sci. 98:6108-6118. https://doi .org/10.3168/jds.2014-8957.

Kaufman, E. I., S. J. LeBlanc, B. W. McBride, T. F. Duffield, and T. J. DeVries. 2016. Association of rumination time with subclinical ketosis in transition dairy cows. J. Dairy Sci. 99:5604-5618. https: //doi.org/10.3168/jds.2015-10509.

King, M. T. M., S. J. LeBlanc, E. A. Pajor, T. C. Wright, and T. J. DeVries. 2018. Behavior and productivity of cows milked in automated systems before diagnosis of health disorders in early lactation. J. Dairy Sci. 101:4343-4356. https://doi.org/10.3168/ jds.2017-13686.

McArt, J. A. A., D. V. Nydam, and G. R. Oetzel. 2012. Epidemiology of subclinical ketosis in early lactation dairy cattle. J. Dairy Sci 95:5056-5066. https://doi.org/10.3168/jds.2012-5443.

Nikkhah, A., C. J. Furedi, A. D. Kennedy, G. H. Crow, and J. C. Plaizier. 2008. Effects of feed delivery time on feed intake, milk production, and blood metabolites of dairy cows. J. Dairy Sci. 91:4249-4260. https://doi.org/10.3168/jds.2008-1075.
Nir Markusfeld, O. 2003. What are production diseases, and how do we manage them? Acta Vet. Scand. Suppl. 98:21-32. https://doi .org/10.1186/1751-0147-44-S1-P1.

Oetzel, G. R. 2007. Herd-level ketosis-Diagnosis and risk factors. Pages 67-91 in Proc. Am. Assoc. Bovine Pract. 40th Annu. Conf. Am. Assoc. Bovine. Pract., Stillwater, OK. Vancouver, BC, Canada.

Plaizier, J. C., D. O. Krause, G. N. Gozho, and B. W. Mcbride. 2009. Subacute ruminal acidosis in dairy cows: The physiological causes, incidence and consequences. Vet. J. 176:21-31. https://doi.org/10 $.1016 / j . t v j 1.2007 .12 .016$.

Raboisson, D., M. Mounié, and E. Maigné. 2014. Diseases, reproductive performance, and changes in milk production associated with subclinical ketosis in dairy cows: A meta-analysis and review. J. Dairy Sci. 97:7547-7563. https://doi.org/10.3168/jds.2014-8237.

Richardt, W. 2004. Milk composition as an indicator of nutrition and health. The Breeding 11:26-27.

SAS Institute. 2013. SAS version 9.4. SAS Institute Inc., Cary, NC.

Schwab, C. G., and G. A. Broderick. 2017. A 100-year review: Protein and amino acid nutrition in dairy cows. J. Dairy Sci. 100:1009410112. https://doi.org/10.3168/jds.2017-13320.

Tatone, E. H., T. F. Duffield, S. J. LeBlanc, T. J. DeVries, and J. L. Gordon. 2017. Investigating the within-herd prevalence and risk factors for ketosis in dairy cattle in Ontario as diagnosed by the test-day concentration of $\beta$-hydroxybutyrate in milk. J. Dairy Sci. 100:1308-1318. https://doi.org/10.3168/jds.2016-11453.

White, H. M. 2015. The role of TCA cycle anaplerosis in ketosis and fatty liver in periparturient dairy cows. Animals (Basel) 5:793-802 https://doi.org/10.3390/ani5030384. 